\title{
ASSESSMENT OF ACOUSTIC AND THERMAL PROPERTIES OF AIRTIGHT WOODEN WINDOWS USED IN BALTIC AND SCANDINAVIAN COUNTRIES
}

\author{
Kęstutis MIŠKINIS*, Raimondas BLIŪDŽIUS, Vidmantas DIKAVIČIUS, Arūnas BURLINGIS \\ Institute of Architecture and Construction, Building Physics Laboratory, Kaunas University of Technology, \\ Tunelio g. 60, LT-44405 Kaunas, Lithuania
}

Received 14 June 2018; accepted 12 February 2019

\begin{abstract}
Windows are the one of the most important elements of a building envelope. Windows with appropriate acoustic and thermal properties can guarantee comfort and protection of indoor environment. The sound and thermal insulation of windows are influenced by various factors and one of them is air tightness. The aim of this study was to assess if airtight typical wooden windows used in Baltic and Scandinavian countries always have both good acoustic and thermal properties. For this purpose, sound reduction index (characterizes acoustic properties), thermal transmittance (characterizes thermal insulation properties) and air permeability (characterizes air tightness) of windows were determined in the laboratory. The results showed that airtight windows have various acoustic and thermal properties. This means that there is a negligible relationship between air permeability and acoustic properties, also between air permeability and thermal properties of windows.
\end{abstract}

Keywords: indoor environment, windows, Baltic, Scandinavian, airtight, acoustic properties, thermal properties.

\section{Introduction}

Building envelope consist of different elements: windows, doors, walls and roof. Windows are of high importance and building indoor environment and living quality of occupants mostly depend on their properties (Allard, Olofsso, \& Hassan, 2013; Ionescu, Baracu, Vlad, Necula, \& Badea, 2015; Kull, Mauring, \& Tkaczyk, 2015; European Union, 2010; Rodríguez-Soria, Domínguez-Hernández, Pérez-Bella, \& Coz Diaz, 2014; Rasmussen \& Gerretsen, 2014; European Union, 2002; Sadineni, Madala, \& Boehm, 2011; Garg, Kumar, \& Maji, 2013; Kurra \& Dal, 2012; Mateus, Pereira, \& Tadeu, 2013; Konroyd-Bolden \& Liao, 2015; Baldinelli et al., 2014; Cuce \& Riffat, 2015; Buratti, Barelli, \& Moretti, 2013; Granzotto et al., 2017). The sound and thermal insulation of windows are influenced by various factors and one of them is air tightness (Iordache \& Catalina, 2012; Varshney, Rosa, Shapiro, \& Scott, 2013; Park \& Kim, 2015; Blasco, Belis, \& Den Bleecker, 2011). Therefore, it is important to know the relationship between air tightness and sound and thermal insulation. The Iordache and Catalina research showed that the air change rate is inverse correlated to the sound transmission loss; the higher the sound transmission loss, the smaller the air infiltration rate. Also these researchers noticed that no direct correlation between sound and thermal insulation could be found: high sound insulation index values do not always correspond to low transmittance and vice versa. Park and Kim in their research say that windows age with time and deteriorate continuously in performance, and sound insulation performance of windows (single window $2-4 \mathrm{~dB}$ and of dual windows about $10 \mathrm{~dB}$ ) can be improved by increasing airtightness. Blasco with colleagues in their research state that if the sound insulation is less than $37 \mathrm{~dB}$ of the glazing, the frame of window does not have the impact on sound insulation of window. Several researches have shown dependence of sound and thermal insulation from air tightness of windows (Blasco et al., 2011; Iordache \& Catalina 2012; Van Den Bossche \& Janssens, 2016). Van Den Bossche and Janssens in their research state that $75 \%$ of analyzed windows have an air leakage rate below $1.05 \mathrm{~m} / \mathrm{h} \cdot \mathrm{m}^{2}$ - this means that they are airtight. Also several of the tested windows show an excellent performance (air flow rate is below $0.1 \mathrm{~m} / \mathrm{h} \cdot \mathrm{m}^{2}$ ). The researchers concluded that if air tightness is high the sound and thermal insulation are also high; and in reverse, when air tightness is low - deterioration of sound and thermal insulation occurs due to the

*Corresponding author. E-mail: kestutis.miskinis@ktu.lt 
gap formed between the outside frame and the window frame (Granzotto et al., 2017; Park \& Kim 2015; Blasco et al., 2011; Iordache \& Catalina, 2012; Van Den Bossche, Huyghe, Moens, Janssens, \& Depaepe, 2012). Most common defects that gave rise to excessive air leakage were weather strip discontinuity, poor sash fit and malfunctioning hardware (Iordache \& Catalina, 2012; Van Den Bergh, Hart, Jelle, \& Gustavsen, 2013). Also researchers noticed that when windows have low airtightness, there is strong relationship between airtightness and sound and thermal insulation (Park \& Kim, 2015). The creation of a discontinuity in the gasket resulted in a reduction of the acoustic insulation in the mid and higher frequencies as the usage of no gasket at all clearly impacts reduces the sound insulation in all frequency range (Blasco et al., 2011). The air tightness of windows usually is characterized by air permeability to the length of opening joints (VL) and, as it is reported by various researches, are different for every type of windows (Van Den Bossche \& Janssens, 2016; Nurzyński, 2003). Nurzyński in his research says that a reduction of window air tightness by making a different kind of slot in the sealing system usually causes a drop in sound insulation in the range of (500-1600) Hz. Weatherstrips acting as a casement supporting element influence the sound insulation of window. Within an analyzed group, window systems with more "pliable" weatherstrips show better acoustic performance. Also results of laboratory measurements show that the reduction of window air tightness causes a significant decrease in their sound insulation, particularly in the case of windows with high insulating glazing. The drop of sound reduction index values is, however, different, even when taking into account only windows with the same glazing. These researchers giving air permeability values of airtight windows have not assessed how it influences both sound and thermal insulation of windows. The aim of this study was to assess if airtight windows always have both good acoustic and thermal properties. The typical wooden windows, used in Baltic and Scandinavian countries with double and triple glass units having high air tightness $\left(\mathrm{V}_{\mathrm{L}}<0.5 \mathrm{~m}^{3} /(\mathrm{h} \cdot \mathrm{m})\right)$, were chosen from production line. The assessment of windows properties was done by determining sound reduction index, thermal transmittance and air permeability in the laboratory conditions and when the performing analysis of obtained results was done.

\section{Experimental conditions and test specimens}

Properties of windows were determined at the Laboratory of Building Physics of Institute of Architecture and Construction of Kaunas University of Technology. The measurements were performed in the following sequence: measurement of thermal transmittance, sound reduction index and air permeability.

The thermal insulation of windows is characterized by thermal transmittance (U-value). The measurements of $U$ value of windows were performed according to the standard LST EN ISO 12567-1 (Lithuanian Standards Board, 2010e) in a Guarded Hot Box (Figure 1) constructed according to the standard LST EN ISO 8990 (Lithuanian Standards Board, 1994). The heat flow rate and surface and air temperatures on both sides were measured for two hours every minute and average values were calculated to determine thermal transmittance of the tested windows. The uncertainty of measured thermal transmittance value is $2.55 \%$ with $95 \%$ probability. The sound insulation of windows is characterized by weighted sound reduction index $\left(\mathrm{R}_{\mathrm{W}}\right)$. The was determined in special acoustic test facilities (Figure 2) in the Laboratory of Building Physics of Kaunas University of Technology. The acoustic test facilities satisfy requirements of the standards: LST EN ISO 10140-1 (Lithuanian Standards Board, 2010a), LST EN ISO 10140-2 (Lithuanian Standards Board, 2010b), LST EN ISO 10140-4 (Lithuanian Standards Board, 2010c),

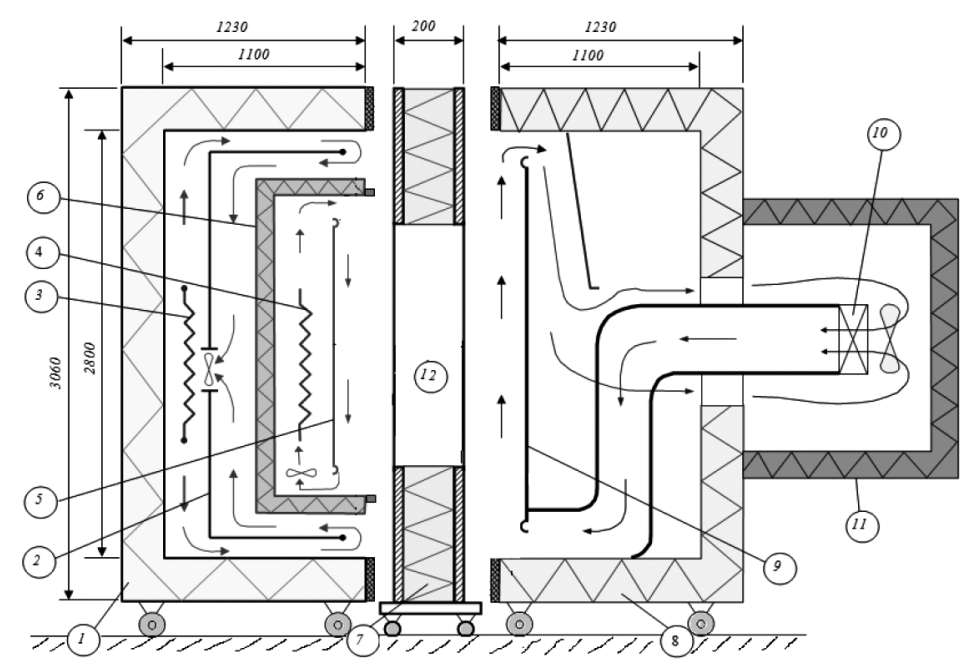

Figure 1. Cross-section of the Hot Box; 1 - Warm guard box; 2 - Protective galvanized pane metal shield for airflow distribution around metering box; 3, 4 - Electric coil heater; 5 - Metering box baffle; 6 - Metering box; 7 - Surround panel; 8 - Cold side box; 9 - Cold side box baffle; 10 - Cooling unit of cold side box; 11 - Air make-up section of cold side; 12 - opening for window 
a)

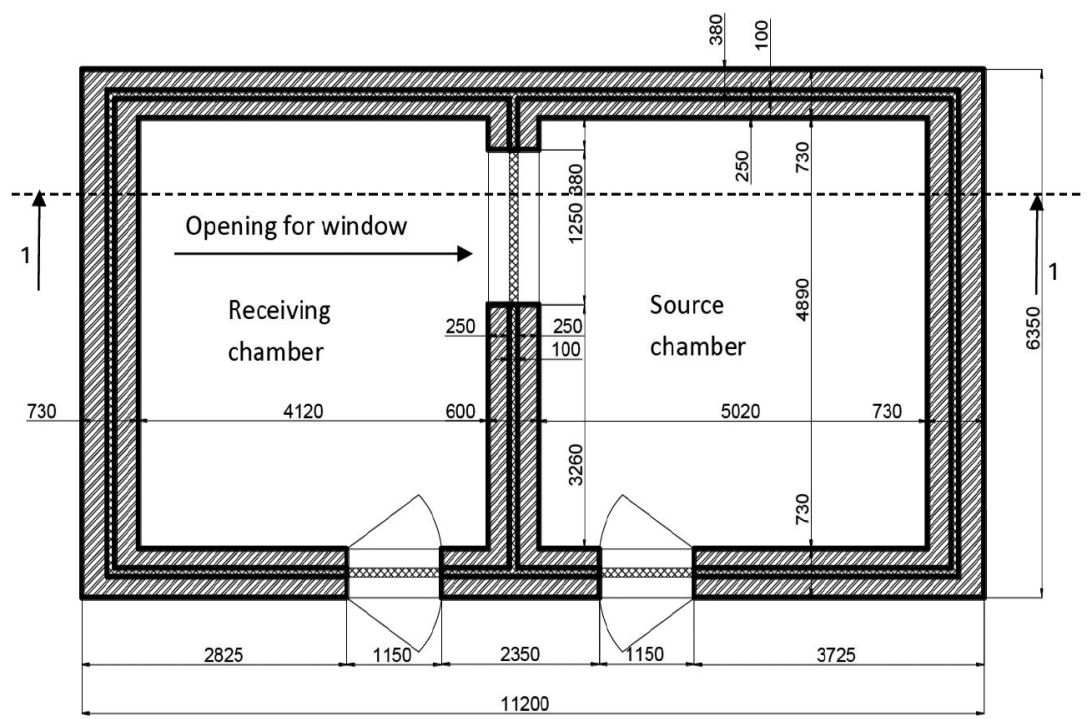

b)

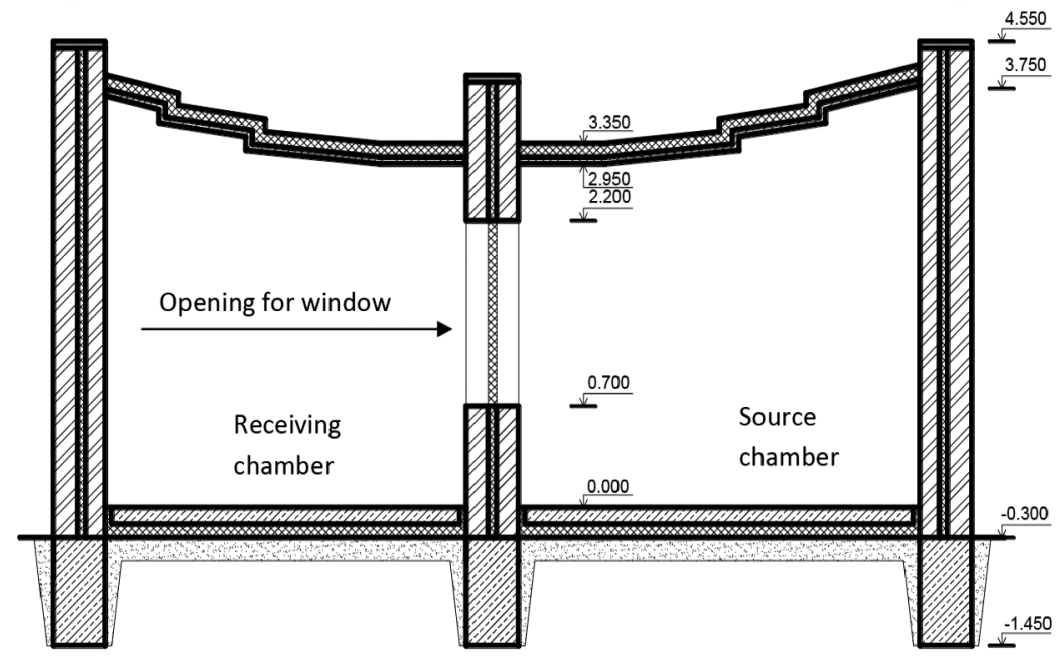

Figure 2. Acoustic test facilities: a) layout; b) vertical cross section "1-1"

LST EN ISO 10140-5 (Lithuanian Standards Board, 2010d) and are verified by performing measurements in Acoustic Laboratory of Building Research Institute, Warsaw, Poland. The maximum sound insulation $\left(\mathrm{R}_{\mathrm{w}, \max }\right)$ of separating filling wall with closed opening for window is $75 \mathrm{~dB}$ and acoustic test facilities could be used for window with sound insulation ( $\mathrm{Rw}$ ) up to $55 \mathrm{~dB}$. The acoustic test facilities consist of source and receiving chambers, whose volumes are respectively $79.95 \mathrm{~m}^{3}$ and $68.56 \mathrm{~m}^{3}$. The chambers are separated by filling wall with the opening of dimensions $1500 \times 1250 \mathrm{~mm}$ for the windows. The filling wall consists of two brickwork lines with mineral wool interlayer. The roof consists of concrete slabs and mineral wool layer. The concrete floating floors are separated from surrounding walls by mineral wool interlayer. The measurements according to standards: LST EN ISO 10140-1 (Lithuanian Standards Board, 2010a), LST EN ISO 10140-2 (Lithuanian Standards Board, 2010b), LST EN ISO 10140-4 (Lithuanian Standards Board, 2010c), LST EN ISO 10140-5 (Lithuanian Standards Board, 2010d) and the evaluation of results according to standard LST EN ISO
717-1 (Lithuanian Standards Board, 2013) in 1/3 octave frequency band from $100 \mathrm{~Hz}$ to $5000 \mathrm{~Hz}$ were performed. The sound insulation measurements using combination of three loudspeaker and six microphone positions were performed. The average value from 18 measurements was calculated. The uncertainty (reproducibility standard deviation) of measurements in 1/3-octave bands with $95 \%$ probability is respectively: for $100-200 \mathrm{~Hz}-1.8-2.3 \mathrm{~dB}$, for $250-500 \mathrm{~Hz}-0.8-1.3 \mathrm{~dB}$, for $630-2500 \mathrm{~Hz}-0.3-$ $0.9 \mathrm{~dB}$ and for $3150-5000 \mathrm{~Hz}-1.1 \mathrm{~dB}$.

The air tightness of windows is characterized by air permeability to the length of opening joints (VL). The air permeability is determined according to the standard LST EN 1026 (Lithuanian Standards Board, 2000) in the special test rig KS 3025/45 ASD SPS (Figure 3). The air permeability of windows was measured in the range from $0 \mathrm{~Pa}$ to $600 \mathrm{~Pa}$. The values of air permeability are given at $600 \mathrm{~Pa}$ pressure in this study because it best indicates air tightness of windows. The air permeability value is the average of values measured at positive and negative pressure. The results are expressed in accordance with standard 


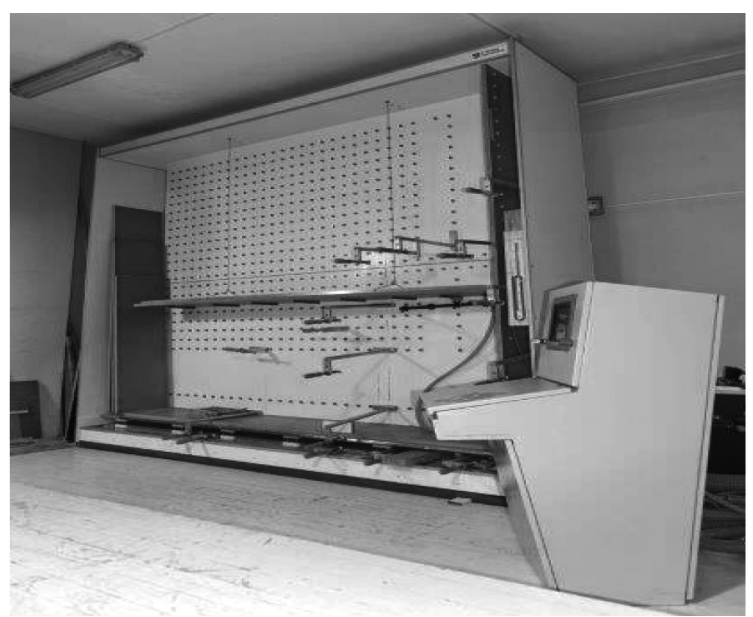

Figure 3. Test rig KS 3025/45 ASD SPS

LST EN 12207 (Lithuanian Standards Board, 1999). The expanded uncertainty with $95 \%$ probability of measurements is $0.035 \mathrm{~m}^{3} /(\mathrm{h} \cdot \mathrm{m})$.

The typical wooden Scandinavian (SW) and European (EW) type windows with double and triple insulated glass unit (IGU), which are usually used in buildings in Baltic and Scandinavian countries in the last decade, were chosen for this study (Table 1).

The dimensions of all tested windows are the same $1230 \times 1480 \mathrm{~mm}$ (width $\times$ height). The thicknesses of the frames and sashes are in the range of 50-110 $\mathrm{mm}$ and $50-90 \mathrm{~mm}$ respectively. The frame and sash of both type windows are made from glued (4 layers) finger-jointed pine (density $520 \mathrm{~kg} / \mathrm{m}^{3}$ ) and painted with white paints from both sides. The horizontal lower edge of frame and sash from outside was covered with painted aluminium strips ( $2 \mathrm{~mm}$ thickness). There were $6-7$ the sash locking points in both types of windows. The mass of both types of windows varies in the range of $40.2-43.2 \mathrm{~kg}$ for double glazed windows and $52.7-57.3 \mathrm{~kg}$ for triple glazed windows. 24 of 33 windows are with triple IGU and 9 are with double IGU. The thickness of glass panes in all IGU are the same $-4 \mathrm{~mm}$. The thickness of gap between glass panes varies with $2 \mathrm{~mm}$ step from $16 \mathrm{~mm}$ up to $22 \mathrm{~mm}$ of double IGU and from $10 \mathrm{~mm}$ up to $24 \mathrm{~mm}$ of triple IGU. The 22 of the 33 of IGU are with non-metallic (NM) and 11 with metallic (M) spacers. The double IGU have one low emissivity coating (layer of silver) on the inside glass and triple IGU - two low emissivity coatings: one on the inside glass and one on the outside glass. The gaps between glass panes are filled with argon gas (90\%) and air (10\%). Weatherstrips are made from EPDM rubber of tube shape. Two weatherstrips are used in the perimeter of window in the external and internal position. The $2 / 3$ of the studied windows are European and $1 / 3$ windows are Scandinavian. The area of glass/frame is $70 \% / 30 \%$ of Scandinavian windows and 68\% / 32\% of European windows. All tested windows had two gaskets in the channels of the perimeter of frame and sash (Figure 4 and Figure 5). The same windows were used for all the tests.
Table 1. Tested windows

\begin{tabular}{|c|c|c|c|c|}
\hline Window & $\begin{array}{l}\text { Spacer } \\
\text { material }\end{array}$ & IGU & Type & Opening type \\
\hline WW-1 & NM & $4-16-4$ & SW & outside \\
\hline WW-2 & M & $4-16-4$ & EW & inside \\
\hline WW-3 & NM & $4-16-4$ & SW & outside \\
\hline WW-4 & NM & $4-16-4$ & SW & outside \\
\hline WW-5 & $\mathrm{M}$ & $4-16-4$ & EW & inside \\
\hline WW-6 & M & $4-16-4$ & EW & inside \\
\hline WW-7 & NM & $4-18-4$ & SW & outside \\
\hline WW-8 & NM & $4-20-4$ & EW & inside \\
\hline WW-9 & NM & $4-22-4$ & SW & outside \\
\hline WW-10 & NM & $4-10-4-10-4$ & SW & outside \\
\hline WW-11 & NM & $4-12-4-12-4$ & EW & inside \\
\hline WW-12 & NM & $4-12-4-12-4$ & SW & outside \\
\hline WW-13 & M & $4-12-4-12-4$ & EW & inside \\
\hline WW-14 & NM & $4-12-4-12-4$ & SW & outside \\
\hline WW-15 & M & 4-14-4-14-4 & EW & inside \\
\hline WW-16 & M & 4-14-4-14-4 & SW & outside \\
\hline WW-17 & M & $4-14-4-14-4$ & EW & inside \\
\hline WW-18 & M & $4-14-4-16-4$ & EW & inside \\
\hline WW-19 & NM & 4-14-4-14-4 & EW & inside \\
\hline WW-20 & M & $4-16-4-16-4$ & EW & inside \\
\hline WW-21 & NM & $4-16-4-16-4$ & EW & inside \\
\hline WW-22 & NM & $4-16-4-16-4$ & SW & outside \\
\hline WW-23 & NM & 4-16-4-18-4 & SW & outside \\
\hline WW-24 & NM & $4-18-4-16-4$ & SW & outside \\
\hline WW-25 & NM & 4-18-4-18-4 & EW & inside \\
\hline WW-26 & NM & 4-18-4-18-4 & EW & inside \\
\hline WW-27 & M & $4-18-4-18-4$ & EW & inside \\
\hline WW-28 & NM & $4-18-4-18-4$ & EW & inside \\
\hline WW-29 & NM & $4-20-4-20-4$ & EW & inside \\
\hline WW-30 & NM & $4-20-4-20-4$ & EW & inside \\
\hline WW-31 & NM & $4-20-4-20-4$ & EW & inside \\
\hline WW-32 & M & $4-22-4-22-4$ & EW & inside \\
\hline WW-33 & NM & $4-24-4-20-4$ & EW & inside \\
\hline
\end{tabular}

\section{Results and discussion}

\subsection{Air permeability}

Air permeability to the length of opening joints $\left(\mathrm{V}_{\mathrm{L}}\right)$ of tested windows are given in Figure 6.

As it could be seen from Figure 6 the $V_{L}$ values are spread mostly in the range from $0.0 \mathrm{~m}^{3} /(\mathrm{h} \cdot \mathrm{m})$ up to $0.5 \mathrm{~m}^{3} /(\mathrm{h} \cdot \mathrm{m})$. From the results it can be stated that 21 of 33 windows have low (less $0.2 \mathrm{~m}^{3} /(\mathrm{h} \cdot \mathrm{m})$ ) air permeability and it means that they are very airtight. 12 of 33 windows have air permeability between $0.2 \mathrm{~m}^{3} /(\mathrm{h} \cdot \mathrm{m})$ and 
a)

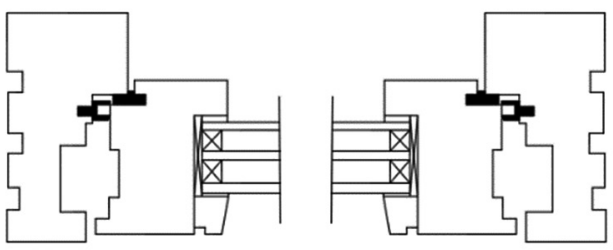

b)
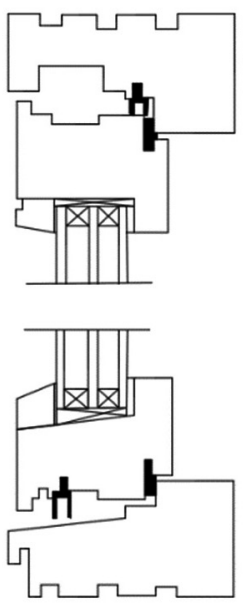

Figure 4. Cross section of Scandinavian type window: a) horizontal; b) vertical

$0.5 \mathrm{~m}^{3} /(\mathrm{h} \cdot \mathrm{m})$ and it is considered as airtight. From the Figure 6 it can be said that window type and glazing does not have influence on air permeability of windows. Also it should be added that two gaskets enable to achieve good air tightness of windows.

\subsection{Sound reduction index}

Weighted sound reduction index $\left(\mathrm{R}_{\mathrm{W}}\right)$ values and weighted sound reduction index with transport spectrum adaptation term $\left(\mathrm{R}_{\mathrm{W}}+\mathrm{C}_{\mathrm{tr}}\right)$ values are given in Figure 7.

From Figure 7 it can be seen that sound insulation of windows expressed by $R_{W}$ vary in the range from $32 \mathrm{~dB}$ up to $36 \mathrm{~dB}$ (the difference is $4 \mathrm{~dB}$ ) and $\mathrm{R}_{\mathrm{W}}+\mathrm{C}_{\mathrm{tr}}$ - from 28 to $31 \mathrm{~dB}$ (the difference is $3 \mathrm{~dB}$ ). From this it can be a)
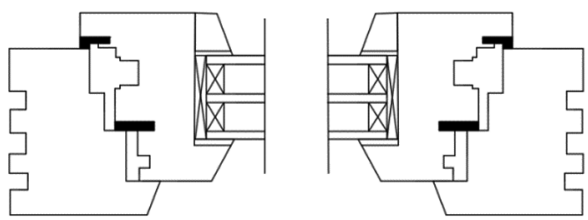

b)
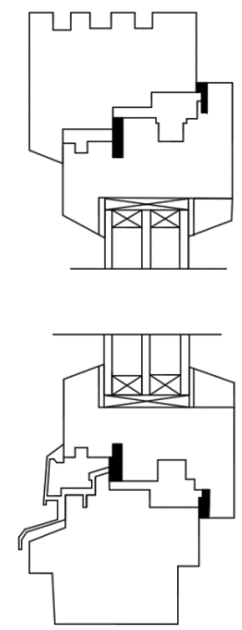

Figure 5. Cross section of European type window:

a) horizontal; b) vertical

seen that all tested windows have similar sound insulation. The sound insulation of European type double and triple glazed windows is from $33 \mathrm{~dB}$ to $36 \mathrm{~dB}$ (difference is $3 \mathrm{~dB}$ ) for $\mathrm{R}_{\mathrm{W}}$ and from $28 \mathrm{~dB}$ to $30 \mathrm{~dB}$ for $\mathrm{R}_{\mathrm{W}}+\mathrm{C}_{\mathrm{tr}}$ (difference is $2 \mathrm{~dB}$ ) and of Scandinavian type windows respectively is from $32 \mathrm{~dB}$ to $35 \mathrm{~dB}$ (difference is $3 \mathrm{~dB}$ ) for $R_{W}$ and from $28 \mathrm{~dB}$ to $31 \mathrm{~dB}$ (difference is $3 \mathrm{~dB}$ ) for $\mathrm{R}_{\mathrm{W}}+\mathrm{C}_{\mathrm{tr}}$. The results show that transport spectrum adaption term $\left(\mathrm{C}_{\mathrm{tr}}\right)$ significantly reduces the sound insulation of windows - from $4 \mathrm{~dB}$ to $6 \mathrm{~dB}$. This shows that both types of windows have a low sound insulation in low frequency range. From the values given in Figure 7 it could be said that sound insulation of windows mostly depends on glazing (number of glass panes, thickness of gap (gas spaces) between glass panes). Increasing the number of

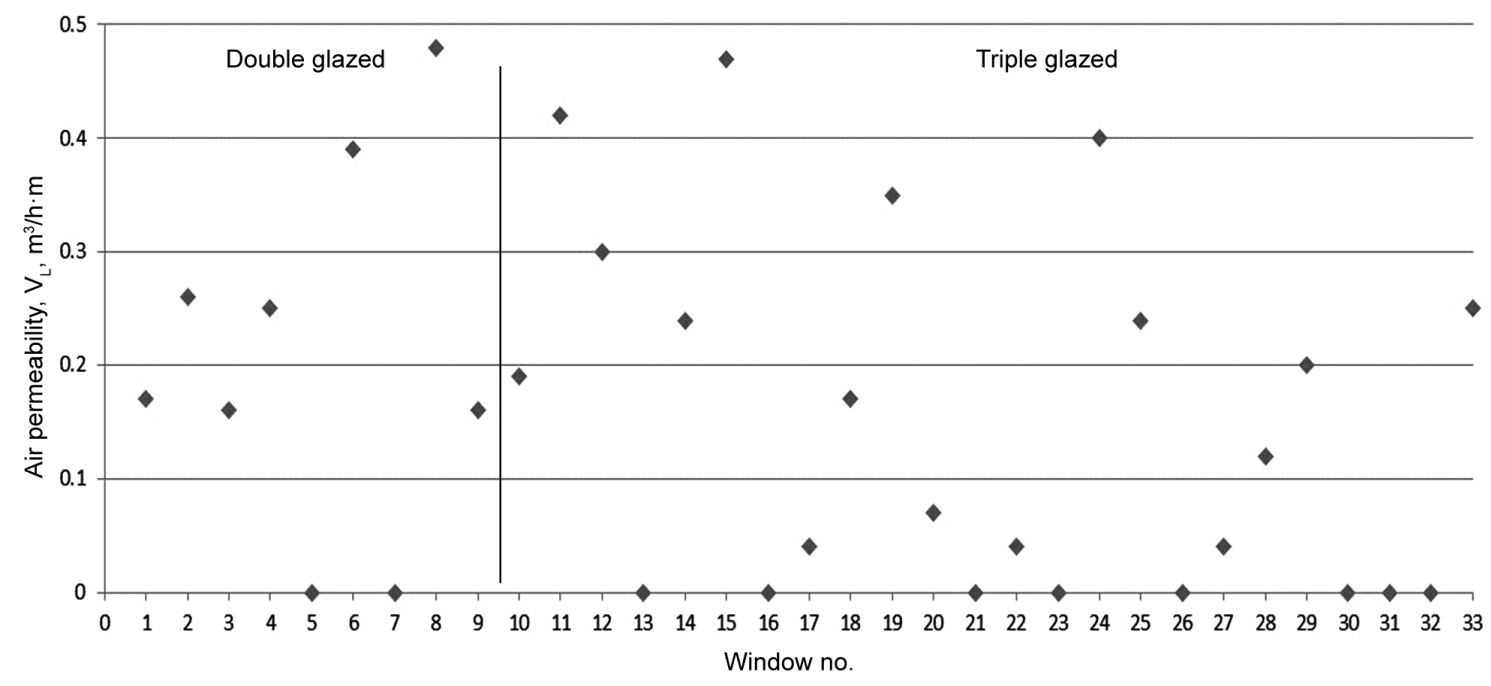

Figure 6. Air permeability to the length of opening joins (VL) at 600 Pa pressure 
glass panes (from 2 to 3 ) and thickness between glass panes (from $10 \mathrm{~mm}$ to $22 \mathrm{~mm}$ ), better sound insulation by $4 \mathrm{~dB}$ is achieved. Also from the results it can be said that type of window does not impact (difference up to $2 \mathrm{~dB}$ ) sound insulation significantly. Therefore, it could be concluded that sound insulation of windows is mainly influenced by glass unit.

\subsection{Thermal transmittance}

The thermal transmittance $(\mathrm{U})$ values are given in Figure 8. Performance of tested windows is given in Table 2 .

From Figure 8 it could be seen that the thermal transmittance $(\mathrm{U})$ of windows varies in the range from $1.6 \mathrm{~W} /\left(\mathrm{m}^{2} \cdot \mathrm{K}\right.$ ) to $0.79 \mathrm{~W} /\left(\mathrm{m}^{2} \cdot \mathrm{K}\right.$ ) (difference is $\left.0.81 \mathrm{~W} /\left(\mathrm{m}^{2} \cdot \mathrm{K}\right)\right)$. The Uw for Scandinavian windows varies from $1.6 \mathrm{~W} /\left(\mathrm{m}^{2} \cdot \mathrm{K}\right)$ up to $0.87 \mathrm{~W} /\left(\mathrm{m}^{2} \cdot \mathrm{K}\right.$ ) (difference $\left.0.73 \mathrm{~W} /\left(\mathrm{m}^{2} \cdot \mathrm{K}\right)\right)$ and for European windows - from
$1.5 \mathrm{~W} /\left(\mathrm{m}^{2} \cdot \mathrm{K}\right)$ to $0.79 \mathrm{~W} /\left(\mathrm{m}^{2} \cdot \mathrm{K}\right)$ (difference $\left.0.71 \mathrm{~W} / \mathrm{m}^{2} \cdot \mathrm{K}\right)$. As it can be seen from the results, the increment of gap (filled with $95 \%$ argon gas) thicknesses, up to $20 \mathrm{~mm}$ between glass panes, decreases the $U$ value. While with gap's thickness over $20 \mathrm{~mm}$ the increment of the U-value appears. Windows with double IGU has about two time worse thermal properties (higher $U$ value) than the windows with triple IGU. The difference of $U$ value between double and triple IGU with the gaps of the same thickness are influenced by different number of glass panes, low emission (LE) coatings and number of gaps. Also from Figure 8 it can be seen that both type windows U-values are similar. Both types of windows have better thermal insulation with non-metallic spacer than with metallic ones due to the lower linear thermal transmittance $(\psi)$ value. The $\psi$ value of non-metallic spacers varies from $0.034 \mathrm{~W} /(\mathrm{m} \cdot \mathrm{K})$ to $0.051 \mathrm{~W} /(\mathrm{m} \cdot \mathrm{K})$ and of metallic spacers $-0.085 \mathrm{~W} /(\mathrm{m} \cdot \mathrm{K})$.

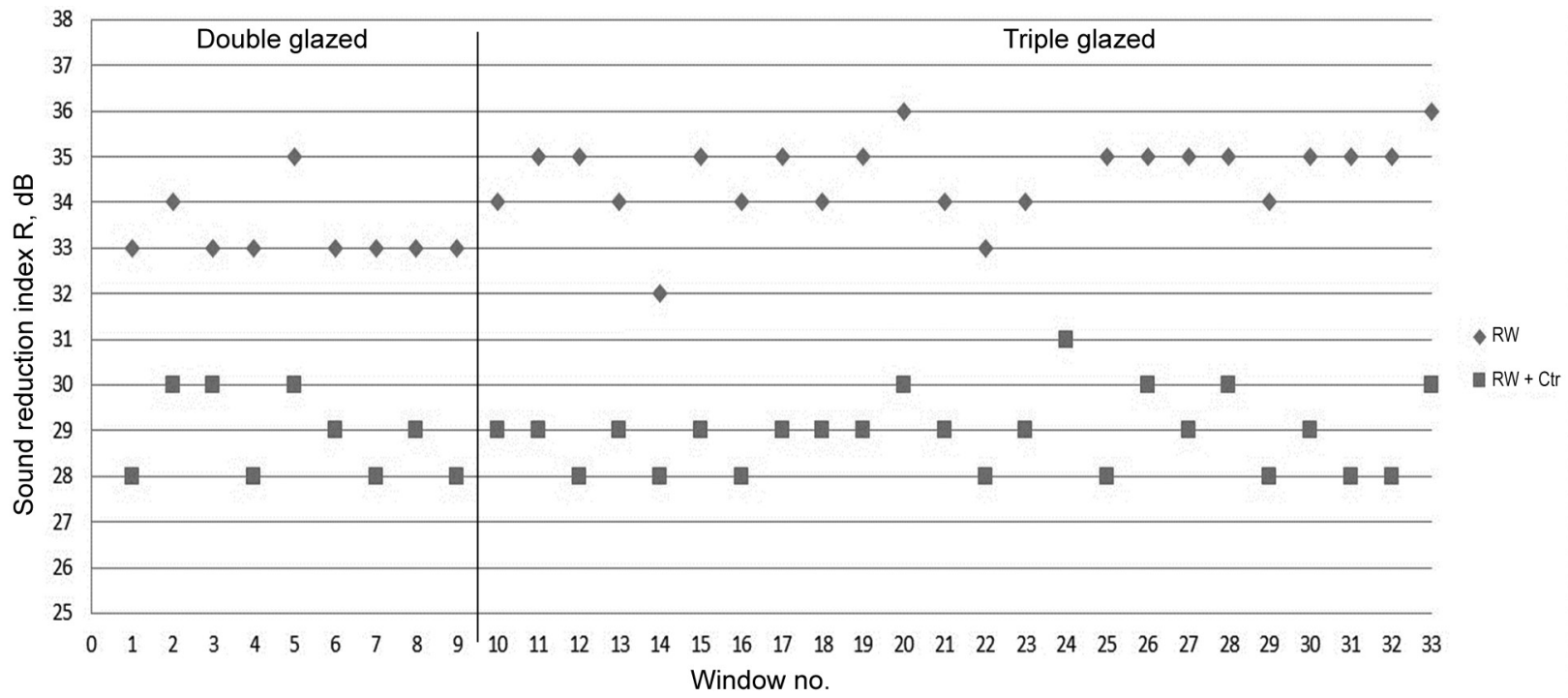

Figure 7. Sound insulation of windows

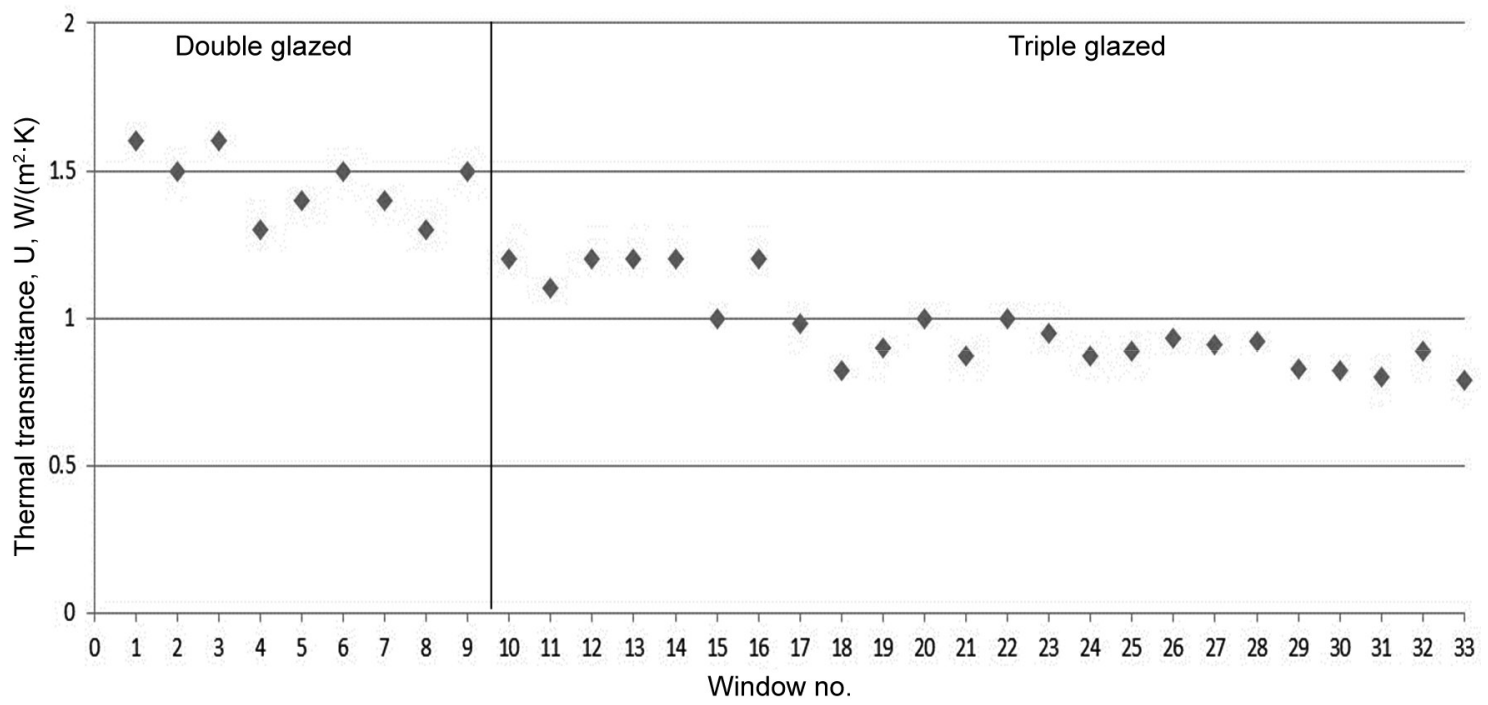

Figure 8. Thermal transmittance of windows 
Table 2. Performance of tested windows

\begin{tabular}{|c|c|c|c|c|c|}
\hline Window & Type & $\begin{array}{c}\mathrm{V}_{\mathrm{L}} \\
\mathrm{m}^{3} /(\mathrm{h} \cdot \mathrm{m})\end{array}$ & $\begin{array}{c}\mathrm{U} \\
\mathrm{W} /\left(\mathrm{m}^{2} \cdot \mathrm{K}\right)\end{array}$ & $\begin{array}{c}\mathrm{R}_{\mathrm{W}}, \\
\mathrm{dB}\end{array}$ & $\begin{array}{c}\mathrm{R}_{\mathrm{W}}+\mathrm{C}_{\mathrm{tr}} \\
\mathrm{dB}\end{array}$ \\
\hline WW-1 & SW & 0.17 & 1.60 & 33 & 28 \\
\hline WW-2 & $\mathrm{EW}$ & 0.26 & 1.50 & 34 & 30 \\
\hline WW-3 & SW & 0.16 & 1.60 & 33 & 30 \\
\hline WW-4 & SW & 0.25 & 1.30 & 33 & 28 \\
\hline WW-5 & EW & 0.00 & 1.40 & 35 & 30 \\
\hline WW-6 & $\mathrm{EW}$ & 0.39 & 1.50 & 33 & 29 \\
\hline WW-7 & SW & 0.00 & 1.40 & 33 & 28 \\
\hline WW-8 & EW & 0.48 & 1.30 & 33 & 29 \\
\hline WW-9 & SW & 0.16 & 1.50 & 33 & 28 \\
\hline WW-10 & SW & 0.19 & 1.20 & 34 & 29 \\
\hline WW-11 & EW & 0.42 & 1.10 & 35 & 29 \\
\hline WW-12 & SW & 0.30 & 1.20 & 35 & 28 \\
\hline WW-13 & EW & 0.00 & 1.20 & 34 & 29 \\
\hline WW-14 & SW & 0.24 & 1.20 & 32 & 29 \\
\hline WW-15 & EW & 0.47 & 1.00 & 35 & 29 \\
\hline WW-16 & SW & 0.00 & 1.20 & 34 & 28 \\
\hline WW-17 & EW & 0.04 & 0.98 & 35 & 29 \\
\hline WW-18 & EW & 0.17 & 0.82 & 34 & 29 \\
\hline WW-19 & EW & 0.35 & 0.90 & 35 & 29 \\
\hline WW-20 & EW & 0.07 & 1.00 & 36 & 30 \\
\hline WW-21 & EW & 0.00 & 0.87 & 34 & 29 \\
\hline WW-22 & SW & 0.04 & 1.00 & 33 & 28 \\
\hline WW-23 & SW & 0.00 & 0.95 & 34 & 29 \\
\hline WW-24 & SW & 0.40 & 0.87 & 35 & 31 \\
\hline WW-25 & EW & 0.24 & 0.89 & 35 & 28 \\
\hline WW-26 & EW & 0.00 & 0.93 & 35 & 30 \\
\hline WW-27 & EW & 0.04 & 0.91 & 35 & 29 \\
\hline WW-28 & EW & 0.12 & 0.92 & 36 & 30 \\
\hline WW-29 & EW & 0.20 & 0.83 & 34 & 28 \\
\hline WW-30 & EW & 0.00 & 0.82 & 35 & 29 \\
\hline WW-31 & EW & 0.00 & 0.80 & 35 & 28 \\
\hline WW-32 & EW & 0.00 & 0.89 & 35 & 28 \\
\hline WW-33 & EW & 0.25 & 0.79 & 36 & 30 \\
\hline
\end{tabular}

From the second table it could be seen that windows with same IGU and spacer in the some cases have the same airtightness, thermal and sound insulation values but in some cases they are different. The windows with double IGU Scandinavian type (WW-3 and WW-4) with the 4-16-4 have sound insulation $(\mathrm{Rw})$ of $33 \mathrm{~dB}$, but different airtightness and $\mathrm{U}$ value is $0.16 \mathrm{~m}^{3} /(\mathrm{h} \cdot \mathrm{m})$ and $0.25 \mathrm{~m}^{3} /(\mathrm{h} \cdot \mathrm{m})$ and $1.60 \mathrm{~W} /\left(\mathrm{m}^{2} \cdot \mathrm{K}\right)$ and $1.30 \mathrm{~W} /\left(\mathrm{m}^{2} \cdot \mathrm{K}\right)$. But with European type windows (WW-5 and WW-6) with the same IGU also sound insulation values differs. The values are $35 \mathrm{~dB}$ and $33 \mathrm{~dB}$ for sound insulation, $0.00 \mathrm{~m}^{3} /(\mathrm{h} \cdot \mathrm{m})$ and $0.39 \mathrm{~m}^{3} /(\mathrm{h} \cdot \mathrm{m})$ for airtightness and $1.40 \mathrm{~W} /\left(\mathrm{m}^{2} \cdot \mathrm{K}\right)$ and $1.50 \mathrm{~W} /\left(\mathrm{m}^{2} \cdot \mathrm{K}\right)$ for $\mathrm{U}$ value. Windows (WW-12 and WW-14; WW-15 and WW-17; WW25, WW-26 and WW-28; WW-29, WW-30 and WW-31) with triple IGU (respectively 4-12-4-12-4, 4-14-4-14-4,
4-18-4-18-4, 4-20-4-20-4) situation is a lit bit different; sound and thermal insulation values are the close, only airtightness varies more. The sound insulation of these windows are in range $32-36 \mathrm{~dB}$, thermal insulation (U-value) from $1.2 \mathrm{~W} /\left(\mathrm{m}^{2} \cdot \mathrm{K}\right)$ to $0.80 \mathrm{~W} /\left(\mathrm{m}^{2} \cdot \mathrm{K}\right)$ and airtightness is from $0.47 \mathrm{~m}^{3} /(\mathrm{h} \cdot \mathrm{m})$ to $0.00 \mathrm{~m}^{3} /(\mathrm{h} \cdot \mathrm{m})$. From this, it could be remarked that it is very difficult to determine the relationship between airtightness, thermal and sound insulation and windows properties.

\subsection{Relationship of windows properties}

In Figures 9-11 the relationship between the following parameters: thermal transmittance and air permeability;

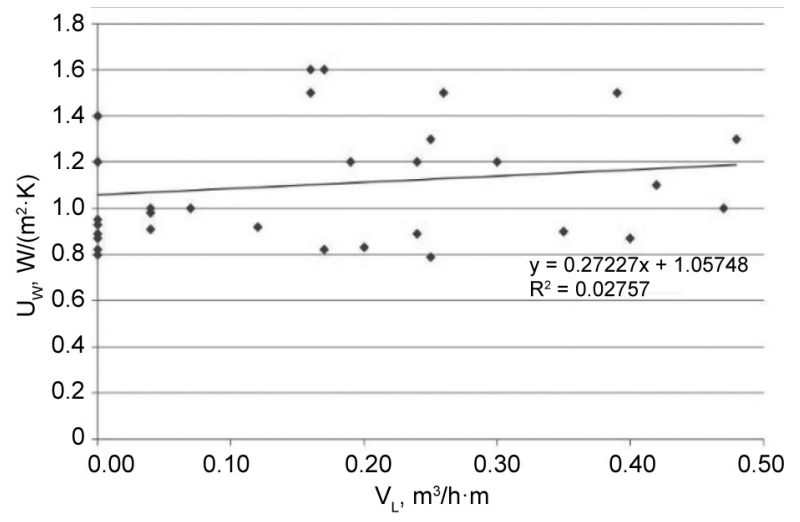

Figure 9. Relationship between thermal transmittance and air permeability

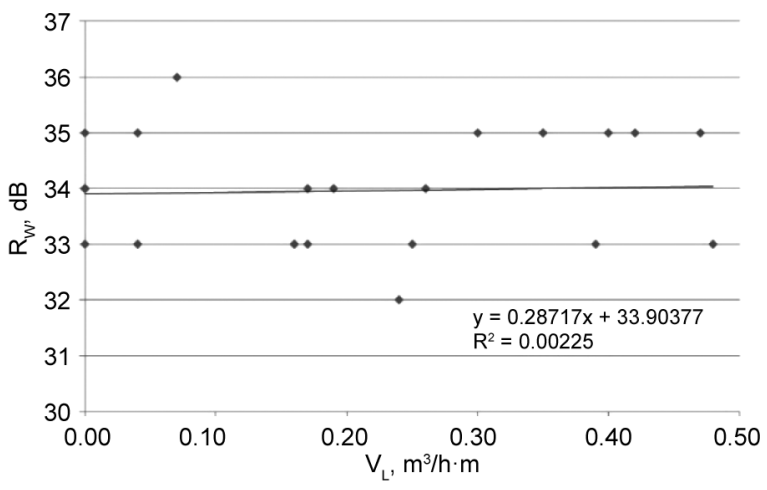

Figure 10. Relationship between weighted sound reduction index and air permeability

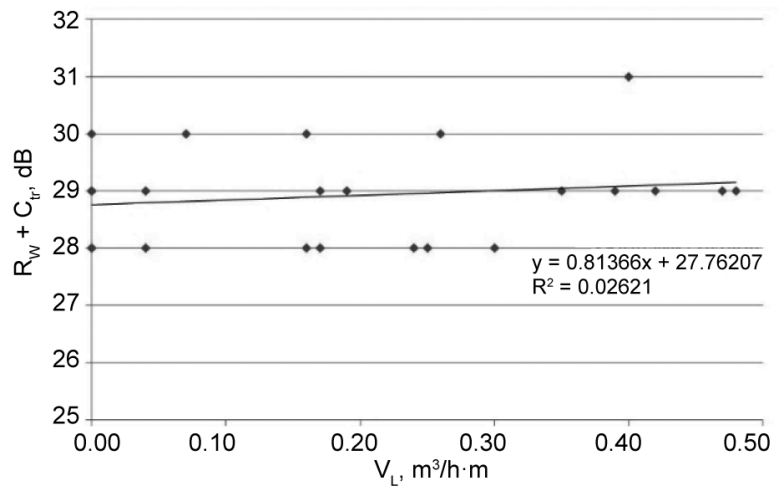

Figure 11. Relationship between weighted sound reduction index with spectrum adaptation term of transport and air permeability 
weighted sound reduction index and air permeability; weighted sound reduction index with spectrum adaptation term of transport and air permeability are given.

The coefficient of determination and Pearson coefficient for evaluation of the relationship of windows properties was calculated. The coefficient of determination shows how close the data are to the fitted regression line as the Pearson coefficient shows the strength of relationship between two parameters. The value of the Pearson coefficient could be from -1 to 1 . If the coefficient value is closer to -1 or 1 it means there is a strong relationship between two analyzed parameters and if it is closer to 0 it means there is no the relationship between them. From Figures 9-11 it can be seen that there is a negligible relationship between the thermal properties and the air permeability as well as the acoustic properties and the air permeability. The coefficient of determination respectively is $0.02757,0.00225$ and 0.02621 . The Pearson coefficient is respectively 0.166 and 0.047 . From this it can be said that if we have airtight windows $\left(\mathrm{V}_{\mathrm{L}}\right.$ less $\left.0.5 \mathrm{~m}^{3} /(\mathrm{h} \cdot \mathrm{m})\right)$, the sound and thermal insulation of these windows it could not be predicted because windows with the same air permeability could have different sound and thermal insulation properties.

\section{Conclusions}

1. The results showed that airtight windows have various both acoustic and thermal properties. The thermal transmittance value of very airtight windows $\left(\mathrm{V}_{\mathrm{L}}<0.2\right)$ is in range 1.6-0.82 and sound insulation is in range 33-36 dB. The thermal transmittance value of the tight windows $\left(\mathrm{V}_{\mathrm{L}}\right.$ 0.2-0.48) is in range 1.6-0.79 and sound insulation is in the same range. From this could be said that very air tight and tight windows have the same thermal and acoustic performance.

2. The sound insulation of windows expressed by $R_{W}$ vary in narrow range and it is from $32 \mathrm{~dB}$ up to $36 \mathrm{~dB}$ (the difference is $4 \mathrm{~dB}$ ) as the thermal transmittance $(\mathrm{U})$ of windows varies in larger range - from $1.6 \mathrm{~W} /\left(\mathrm{m}^{2} \cdot \mathrm{K}\right)$ to $0.7 \mathrm{~W} /\left(\mathrm{m}^{2} \cdot \mathrm{K}\right.$ ) (difference is about $0.8 \mathrm{~W} /\left(\mathrm{m}^{2} \cdot \mathrm{K}\right)$ ). From this it could be said that the reduction of heat loss does not give the same reduction in sound insulation. The relationship between sound and thermal insulation is negligible (0.162). This means that these properties do not influence each other.

3. The analysis of the study results showed that there is a negligible relationship (Pearson coefficient is 0.166) between air permeability and acoustic properties; furthermore, there is a negligible relationship (Pearson coefficient is 0.047 ) between air permeability and thermal properties of windows. This means that these analysed properties of windows very insignificantly influence each other.

4. From air tightness values it cannot be said that windows will have good thermal and sound insulation properties. These properties are influenced by other factors such as used glass sheets (thicker glass sheets gives better sound insulation), used spacers and their thickness (nonmetallic and thicker spacers give better thermal insulation), and glass coatings (two coatings give better thermal insulation).

\section{Author contributions}

K. Miškinis and R. Bliūdžius conceived the study. V. Dikavičius and A. Burlingis performed measurements. K. Miškinis and R. Bliūdžius performed analysis of results. K. Miškinis wrote the draft of paper. R. Bliūdžius, V. Dikavičius and A. Burlingis revised the paper and give their suggestions and comments of results and explanation for expanded analysis of results.

\section{Disclosure statement}

We declare that we did not have any competing financial support, professional, or personal interests from other parties.

\section{References}

Allard, I., Olofsso, N. T., \& Hassan, O. A. B. (2013). Methods for energy analysis of residential buildings in Nordic countries. Renewable and Sustainable Energy Reviews, 22, 306-318. https://doi.org/10.1016/j.rser.2013.02.007

Baldinelli, G., Asdrubali, F., Baldassarri, C., Bianchi, F., D’Alessandro, F., Schiavoni, S., \& Basilicata, C. (2014). Energy and environmental performance optimization of a wooden window: a holistic approach. Energy and Buildings, 79, 114-131. https://doi.org/10.1016/j.enbuild.2014.05.010

Blasco, M., Belis, J., \& Den Bleecker, H. (2011). Acoustic failure analysis of windows in buildings. Engineering Failure Analysis, 18, 1761-1774.

https://doi.org/10.1016/j.engfailanal.2011.03.027

Buratti, C., Barelli, L., \& Moretti, E. (2013). Wooden windows: Sound insulation evaluation by means of artificial neural networks. Applied Acoustics, 74(5), 740-745.

https://doi.org/10.1016/j.apacoust.2012.12.001

Cuce, E., \& Riffat, S. B. (2015). A state-of-the-art study on innovative glazing technologies. Renewable and Sustainable Energy Reviews, 41, 695-714. https://doi.org/10.1016/j.rser.2014.08.084

European Union. (2002). Directive 2002/49/EC of the European Parliament and of the Council of 25 June 2002 relating to the assessment and management of environmental noise - Declaration by the Commission in the Conciliation Committee on the Directive relating to the assessment and management of environmental noise. Retrieved from http://eur-lex.europa.eu/ legal-content/EN/TXT/?uri=CELEX\%3A32002L0049

European Union. (2010). Directive 2010/31/EU of the European Parliament and of the Council of 19 May 2010 on the energy performance of buildings. Retrieved from http://eur-lex.europa.eu/legal-content/EN/TXT/?uri=CELEX:32010L0031

Garg, N., Kumar, A., \& Maji, S. (2013). Significance and implications of airborne sound insulation criteria in building elements for traffic noise abatement. Applied Acoustics, 74, 14291435. https://doi.org/10.1016/j.apacoust.2013.05.012

Granzotto, F., Bettarello, F., Ferluga, A., Marsich, L., Schmid, C., Fausti, P., \& Caniato, M. (2017). Energy and acoustic performances of windows and their correlation. Energy and Buildings, 136, 189-198.

https://doi.org/10.1016/j.enbuild.2016.12.024 
Ionescu, C., Baracu, T., Vlad, G. E., Necula, H., \& Badea, A. (2015). The historical evolution of the energy efficient buildings. Renewable and Sustainable Energy Reviews, 49, 243-253. https://doi.org/10.1016/j.rser.2015.04.062

Iordache, V., \& Catalina, T. (2012). Acoustic approach for building air permeability estimation. Building and Environment, 57, 18-27. https://doi.org/10.1016/j.buildenv.2012.04.008

Konroyd-Bolden, E., \& Liao, Z. (2015). Thermal window insulation. Energy and Buildings, 109, 245-254. https://doi.org/10.1016/j.enbuild.2015.10.005

Kull, T. M., Mauring, T., \& Tkaczyk, A. H. (2015). Energy balance calculation of window glazings in the northern latitudes using long-term measured climatic data. Energy Conversion and Management, 89, 896-906.

https://doi.org/10.1016/j.enconman.2014.10.058

Kurra, S., \& Dal, L. (2012). Sound insulation design by using noise maps. Building and Environment, 49, 291-303. https://doi.org/10.1016/j.buildenv.2011.07.006

Lithuanian Standards Board. (1994). Thermal insulation - Determination of steady-state thermal transmission properties Calibrated and guarded hot box (LST EN ISO 8990). Retrieved from http://lsd.lt

Lithuanian Standards Board. (1999). Windows and doors - Air permeability - Classification (LST EN 12207). Retrieved from http://www.lsd.lt/index.php?-816496186

Lithuanian Standards Board. (2000). Windows and doors - Air permeability - Test method (LST EN 1026). Retrieved from http://www.lsd.lt/index.php?711853454

Lithuanian Standards Board. (2010a). Acoustics - Laboratory measurement of sound insulation of building elements - Part 1: Application rules for specific products (LST EN ISO 10140-1). Retrieved from http://www.lsd.lt

Lithuanian Standards Board. (2010b). Acoustics - Laboratory measurement of sound insulation of building elements - Part 2: Measurement of airborne sound insulation (LST EN ISO 10140-2). Retrieved from http://www.lsd.lt

Lithuanian Standards Board. (2010c). Acoustics - Laboratory measurement of sound insulation of building elements - Part 4: Measurement procedures and requirements (LST EN ISO 10140-4). Retrieved from http://www.lsd.lt

Lithuanian Standards Board. (2010d). Acoustics - Laboratory measurement of sound insulation of building elements - Part 5: Requirements for test facilities and equipment (LST EN ISO 10140-5). Retrieved from http://www.lsd.lt

Lithuanian Standards Board. (2010e). Thermal performance of windows and doors - Determination of thermal transmittance by the hot-box method - Part 1: Complete windows and doors (LST EN ISO 12567-1). Retrieved from http://www.lsd.lt
Lithuanian Standards Board. (2013). Acoustics - Rating of sound insulation in buildings and of building elements - Part 1: Airborne sound insulation (LST EN ISO 717-1). Retrieved from http://www.lsd.lt

Mateus, D., Pereira, A., \& Tadeu, A. (2013). Acoustic behavior of high acoustic performance window glazing. Noise Control Engineering Journal, 61, 320-329.

https://doi.org/10.3397/1/3761027

Nurzyński, J. (2003). Influence of sealing on the acoustic performance of PVC windows. In Proceedings of the Second International Conference on Building Physics (pp. 595-604). Belgium.

Park, K. H., \& Kim, H. (2015). Acoustic insulation performance of improved airtight windows. Construction and Building Materials, 93, 542-550.

https://doi.org/10.1016/j.conbuildmat.2015.05.058

Rasmussen, B., \& Gerretsen, E. (2014). Proposal for an acoustic classification scheme for housing. In COST Action TU0901 Building acoustics throughout Europe. Volume 1: Towards a common framework in building acoustics throughout Europe (pp. 80-100). DiScript Preimpresion, S. L.

Rodríguez-Soria, B., Domínguez-Hernández, J., Pérez-Bella, J. M., \& Coz Diaz, J. J. (2014). Review of international regulations governing the thermal insulation requirements of residential buildings and the harmonization of envelope energy loss. Renewable and Sustainable Energy Reviews, 34, 78-90. https://doi.org/10.1016/j.rser.2014.03.009

Sadineni, S. B., Madala, S., \& Boehm, R. F. (2011). Passive building energy savings: a study of building envelope components. Renewable and Sustainable Energy Reviews, 15, 3617-3631. https://doi.org/10.1016/j.rser.2011.07.014

Van Den Bergh, S., Hart, R., Jelle, B. P., \& Gustavsen, A. (2013). Window spacers and edge seals in insulating glass units: a state-of-the-art study and future perspectives. Energy and Buildings, 58, 263-280.

https://doi.org/10.1016/j.enbuild.2012.10.006

Van Den Bossche, N., \& Janssens, A. (2016). Airtightness and watertightness of window frames: comparison of performance and requirements. Building and Environment, 110, 129-139. https://doi.org/10.1016/j.buildenv.2016.09.034

Van Den Bossche, N., Huyghe, W., Moens, J., Janssens, A., \& Depaepe, M. (2012). Airtightness of the window-wall interface in cavity brick walls. Energy and Buildings, 45, 32-42. https://doi.org/10.1016/j.enbuild.2011.10.022

Varshney, K., Rosa, J. E., Shapiro, I., \& Scott, D. (2013). Air-infiltration measurements in buildings using sound transmission loss through small apertures. International Journal of Green Energy, 10, 482-493.

https://doi.org/10.1080/15435075.2012.675603 